\title{
Case study — tailings dam construction in an arctic climate
}

\author{
F. Esford Golder Associates Ltd., Canada \\ P. Bedell Golder Associates Ltd., Canada \\ E. Lamontange Agnico-Eagle Mines Limited, Canada
}

\begin{abstract}
Agnico-Eagle Mines Limited, operates the Meadowbank Gold Mine, in Nunavut, within the arctic region of Canada where permafrost is widespread. Construction of their mine facilities began in 2008 and production commenced in the first quarter of 2010. The mine will consist of a series of open pits, with conventional processing and slurried tailings deposition within the tailings storage facility. The tailings facility is being constructed in stages through a series of perimeter dams and staged raises to provide adequate tailings storage capacity. The 2009 construction season included the construction of Stage 1 of one such structure, 'Saddle Dam 1', a $10 \mathrm{~m}$ high and $250 \mathrm{~m}$ long, lined rockfill structure, with Stage 2 to be constructed in 2010 to a height of $20 \mathrm{~m}$ and an overall length of $400 \mathrm{~m}$.

The geotechnical investigation determined that soil thicknesses were up to $12 \mathrm{~m}$ with permafrost below the active layer (approximately $1-2 \mathrm{~m}$ ) and the upper $5 \mathrm{~m}$ being ice-rich material. The dam was founded on bedrock on the abutments, and on-ice poor soils within the main body of the dam. Ice-rich soils were blasted and excavated from beneath the upstream portion of the dam foundation. Blanket filters were placed above this area followed by the upstream filters and the installation of a linear low density polyethylene (LLDPE) liner on the dam face. The LLDPE liner was installed at temperatures between -15 and $-25^{\circ} \mathrm{C}$.
\end{abstract}

This paper presents the case study for the successful construction of the structure in challenging arctic conditions.

\section{Introduction}

Agnico-Eagle Mines Limited operates the Meadowbank Gold Mine, in Nunavut, within the arctic region of Canada (Figure 1). Meadowbank is located approximately $70 \mathrm{~km}$ north of the hamlet of Baker Lake. Baker Lake is the only inland Inuit community in Nunavut and is situated on the mouth of the Thelon River on Baker Lake, approximately $300 \mathrm{~km}$ inland from Hudson Bay connected by water through Chesterfield Inlet. The mine is accessed by air and seasonally by barge through Hudson Bay, Chesterfield Inlet and connecting waterways that lead to Baker Lake and then by road from Baker Lake to the mine.

The mine is located along the southern boundary of the Northern Arctic Ecozone, which is characterised as dry and cold, a 'polar desert'. Based on site climatic data, the mean monthly temperature varies from a low of $-32^{\circ} \mathrm{C}$ in January to a high of $12^{\circ} \mathrm{C}$ in July. Mean annual temperature is $-11.4^{\circ} \mathrm{C}$ with the mean monthly temperatures below zero Celsius for eight months of the year, from January through May and October through December. Average annual precipitation is $295 \mathrm{~mm}$ with approximately half of it falling as snow. Prevailing winds are from the northwest and the maximum daily wind gust of $95 \mathrm{~km} / \mathrm{h}$ was recorded in 2009 .

The mine is located within the zone of continuous permafrost, defined as soil or rock at, or below, a temperature of $0^{\circ} \mathrm{C}$ for at least two consecutive years, to an estimated depth of 450 to $550 \mathrm{~m}$. The thickness of the active layer (the upper zone of ground from surface that annually thaws and freezes) varies based on proximity to lakes, soil thickness, vegetation, and slope direction, from about 1.3 up to $4 \mathrm{~m}$. Taliks (thawed zones within permafrost) exist beneath lakes with water depths greater than 2 to $3 \mathrm{~m}$. The permafrost in this area is relatively cold with mean average annual temperatures between -6 to $-8^{\circ} \mathrm{C}$, below the active layer.

Mine construction began in 2008 and production commenced in the first quarter of 2010 . The mine will consist of a series of open pits, with conventional processing and slurried tailings deposition within the tailings storage facility. The tailings facility is being constructed in stages within a portion of a dewatered lake. In 2008, the first dewatering dike was constructed, to isolate a portion of the lake, firstly to expose a 
portion of the lake bed containing reserves that will be mined, and secondly the area beyond the open pit will be used to create the tailings storage facility. A series of perimeter dams are being built and progressively raised to provide adequate tailings storage capacity within this basin (Figure 2).

In 2009, the first stage of a perimeter structure, Saddle Dam 1, was constructed. Saddle Dam 1 consists of a lined rockfill structure, with dimensions of $10 \mathrm{~m}$ high and about $250 \mathrm{~m}$ in length. Stage 2 is to be constructed in 2010, with an overall length of $400 \mathrm{~m}$ and height of $20 \mathrm{~m}$.

This paper presents the design and construction practices used to construct the dam in the challenging arctic conditions.

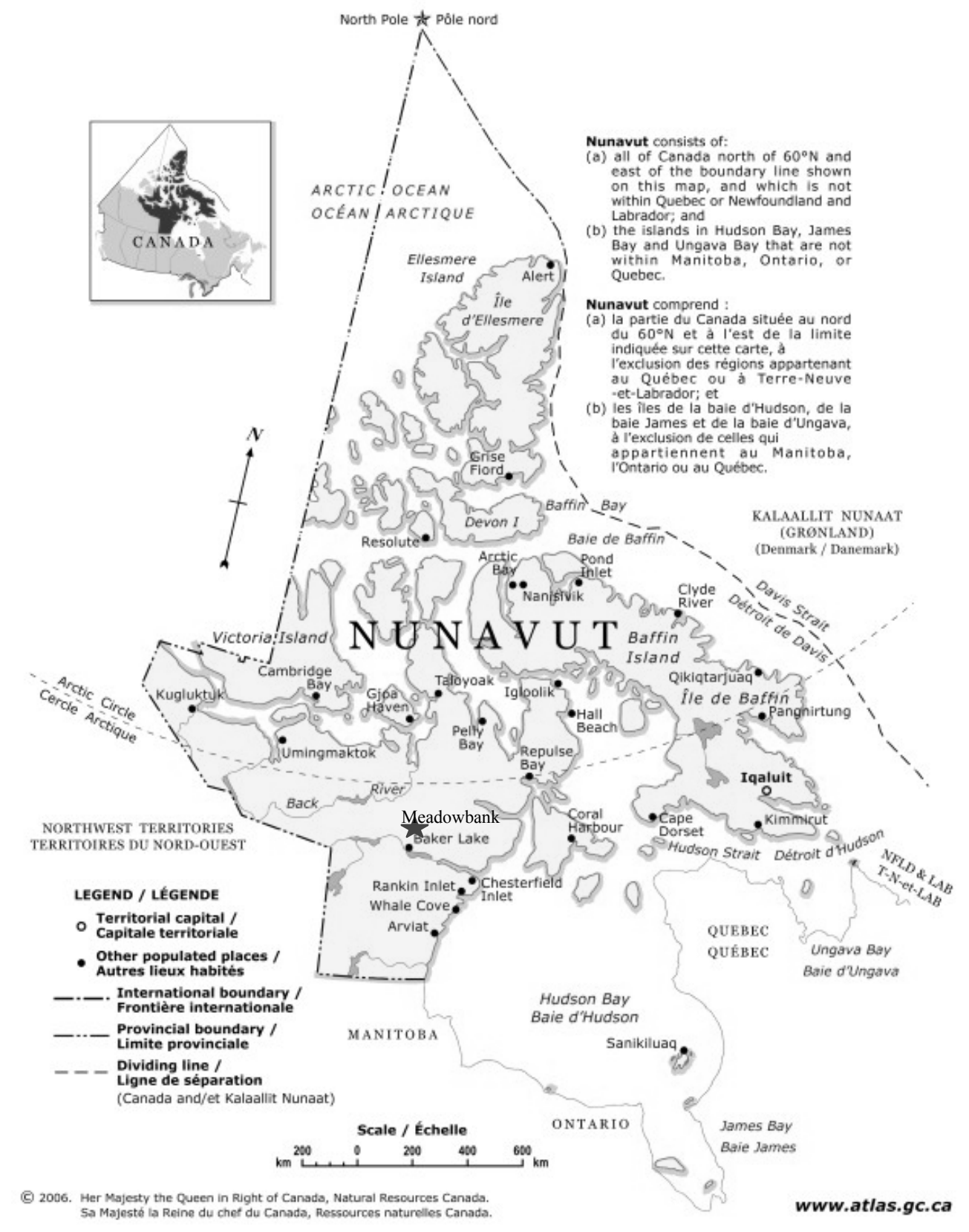

Figure 1 Meadowbank Mine location 


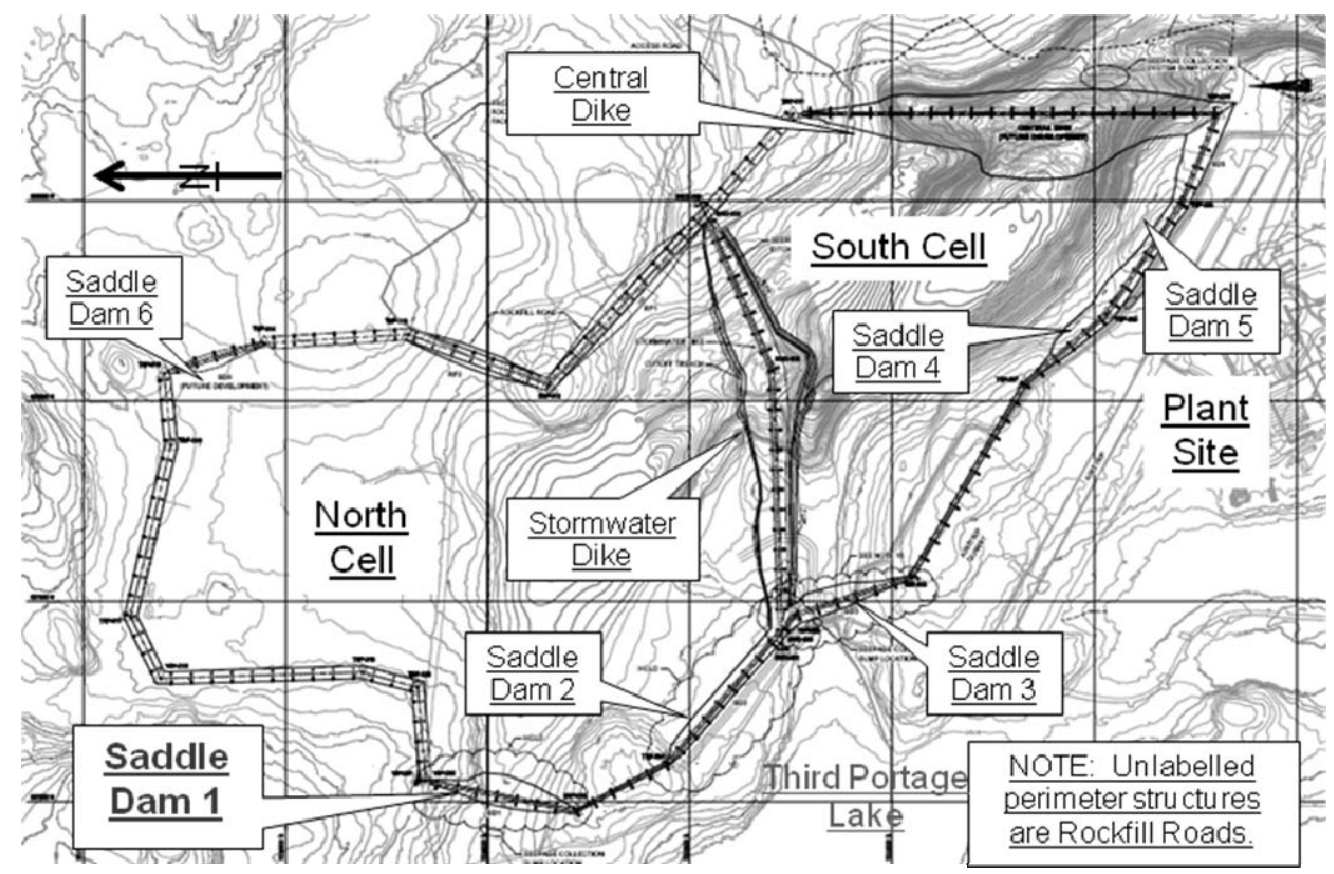

Figure 2 Meadowbank Mine tailings storage facility - Saddle Dam 1 location

\section{Saddle Dam 1 - site conditions}

Prior to constructing Saddle Dam 1, a site investigation was conducted using a combination of an air rotary rig and diamond drill rig. Fourteen air rotary drill holes were advanced which provided information on the depth to bedrock and provided the opportunity for limited characterisation of the soil and relative ice content. One diamond drill hole was advanced at the upstream toe, for recovery of both soil and rock core for better characterisation. In addition, in situ hydraulic conductivity testing within the shallow bedrock was conducted, and a temporary thermistor string was installed to gather thermal data.

The general subsurface soil conditions encountered during the investigation consisted of a relatively thin layer of glaciofluvial deposits (primarily sands and gravels) overlying till materials (primarily well-graded silty sands and gravels, with cobbles and boulders). Soil thicknesses varied from 2 to $12 \mathrm{~m}$, with all soils being frozen. The upper portion of the soil, approximately $5 \mathrm{~m}$, was observed to be ice-rich based on the presence of visible ice lenses and/or water contents in excess of $20 \%$. Ice lenses up to $0.7 \mathrm{~m}$ thick were observed, along with ice with soil inclusions, and stratified ice. The thermistor string data showed that the soil and bedrock were frozen with a temperature of about $-7^{\circ} \mathrm{C}$ to a depth of at least $20 \mathrm{~m}$ below ground surface.

Bedrock is ultramafic volcanic, highly fractured, weathered, and weak near surface with the degree of weathering decreasing with depth and strength increasing. The hydraulic conductivity of the shallow bedrock was relatively high at $3 \times 10^{-5} \mathrm{~cm} / \mathrm{s}$.

Dewatering of the basin where tailings are to be stored had begun prior to the investigation and the dam footprint area was dry (above lake level) during construction.

\section{$3 \quad$ Saddle Dam 1 - design}

The design intent of Saddle Dam 1 is that the structure retains tailings and supernatant water in the north portion of the tailings facility and that it minimises seepage from the tailings facility into Third Portage Lake over the long-term and post-closure. Using Canadian Dam Association (CDA, 2007) classification system, Saddle Dam 1 has a high consequence of failure due to potential for environmental damage by contamination of Third Portage Lake with tailings and/or supernatant water. Other design criteria for the structure are summarised in Table 1. 
The overall tailings facility has been permitted with the design assumption, that after a short period, the tailings will freeze back and permafrost will encapsulate and minimise seepage. However, with climate change it has also been recognised that there is the potential, in the future for the tailings to thaw and therefore the potential for seepage from the facility to increase in the long term. Initially, the potential for thermal variation also exists and therefore a means to reduce seepage was required in the design. Tailings beach development and pond management also is integral in the operation of the tailings facility and seepage control.

Figure 3 shows the typical design section for Saddle Dam 1. Saddle Dam 1 is to be constructed in two stages, with Stage 1 of the dam $10 \mathrm{~m}$ high and $250 \mathrm{~m}$ in length and Stage 2, $20 \mathrm{~m}$ high and $400 \mathrm{~m}$ in length. The design includes:

- foundation preparation with the removal of ice-rich soils beneath the upstream of the dam

- installation of an inverted filter blanket

- rockfill structure with an upstream slope of 3 horizontal to 1 vertical (3H:1V) and a downstream slope of $1.5 \mathrm{H}: 1 \mathrm{~V}$

- processed granular bedding layers (for the geomembrane liner) which also act as an upstream filter

- compacted low hydraulic conductivity till in the upstream toe anchor trench

- geomembrane liner on the upstream face of the dam, with upper and lower non-woven geotextiles for protection

- low hydraulic conductivity material above the geomembrane liner toe

- protective layer of granular material on the upstream face, above the geomembrane liner.

The design includes a contingency for remedial grouting to be conducted through the upstream anchor trench toe and into bedrock in the future, if necessary.

\section{Table 1 Design criteria}

\begin{tabular}{lll}
\hline Design Criteria & Value and/or Description & Source or Comments \\
\hline Freeboard & $\begin{array}{l}2 \mathrm{~m} \text { minimum during operation } \\
1 \mathrm{~m} \text { minimum during closure }\end{array}$ & $\begin{array}{l}\text { Settlement and overtopping } \\
\text { (CDA, 2007) }\end{array}$ \\
$\begin{array}{l}\text { Canadian Dam Association } \\
\text { hazard classification }\end{array}$ & High & $\begin{array}{l}\text { Potential for environmental } \\
\text { damage (CDA, 2007) }\end{array}$ \\
$\begin{array}{l}\text { Seismic event } \\
(1 \text { in 2,500 year return period) }\end{array}$ & $\begin{array}{l}\text { Peak horizontal ground acceleration } \\
=0.04 \mathrm{~g}\end{array}$ & $\begin{array}{l}\text { 2005 National Building Code of } \\
\text { Canada, CDA (2007) }\end{array}$ \\
& $\begin{array}{l}\text { Peak horizontal ground velocity } \\
=0.04 \mathrm{~m} / \mathrm{s}\end{array}$ & \\
Minimum factor of safety for & $\begin{array}{l}\text { End of construction }=1.3 \\
\text { slope stability }\end{array}$ & Steady state, with maximum tailings \\
& $=1.5$ & \\
& Pseudostatic conditions $=1.0$ & \\
& Post closure $=1.5$ & \\
\hline
\end{tabular}




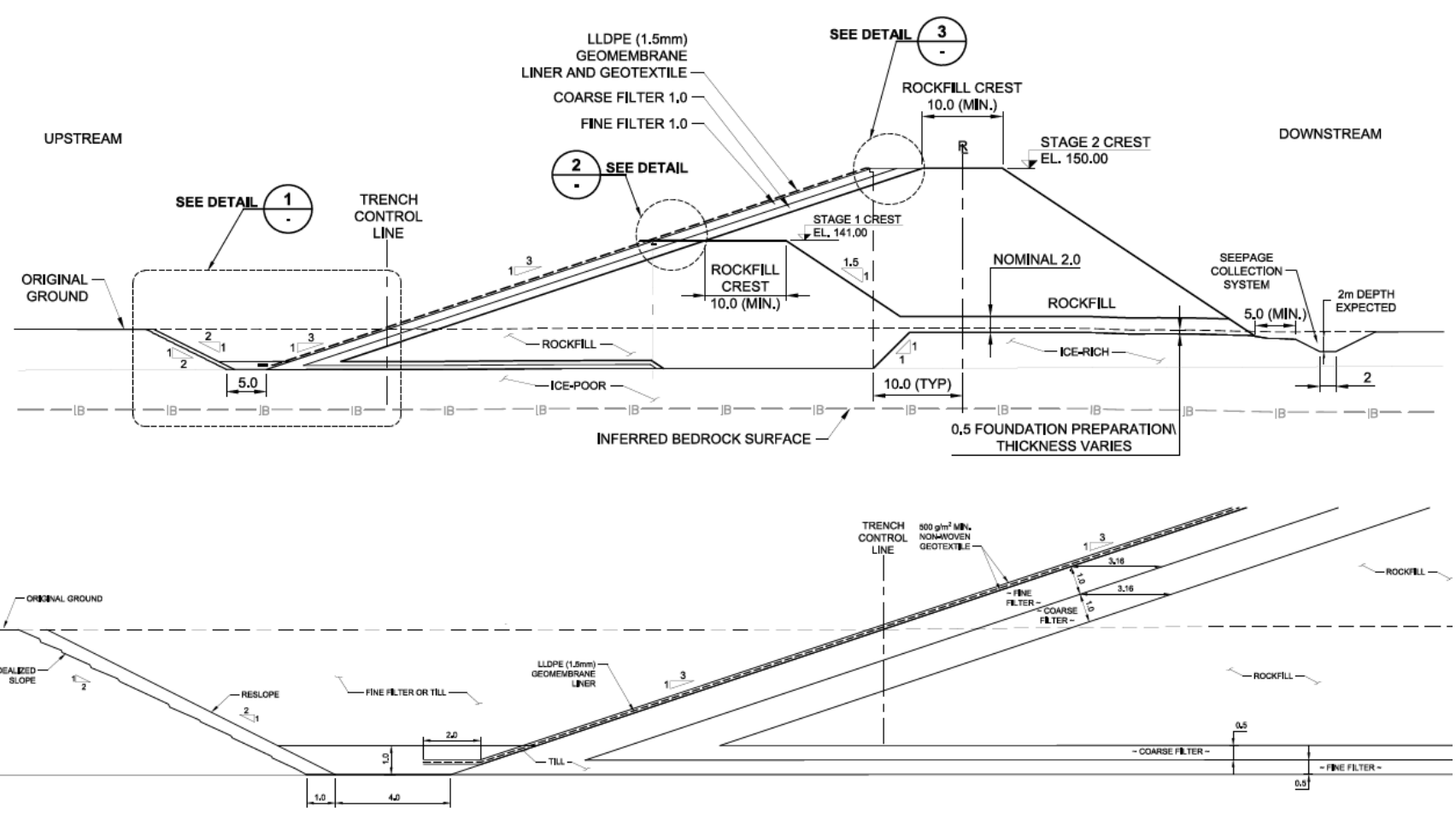

Figure 3 Saddle Dam 1 - typical section

\section{$4 \quad$ Saddle Dam 1 - construction}

Construction of Saddle Dam 1 commenced in August 2009 and was completed in early November.

\subsection{Foundation preparation}

To reduce the potential for differential settlement beneath the upstream portion of the dam, upon which the geomembrane liner was to be installed, the design required that ice-rich soils be removed from this zone.

Foundation preparation consisted of drilling, blasting, and excavation to remove the ice-rich soils, beneath the upstream portion of the dam (both Stage 1 and Stage 2). Approximately the upper $6 \mathrm{~m}$ of material was removed. Confirmation samples of soils left in place were collected and analysed for water content to demonstrate that remaining soils did not contain excess ice. Upon approval of the foundation, placement of the rockfill and inverted filter material commenced immediately to reduce the potential for thawing of the foundation soils left in place.

On the abutments, soil was removed and bedrock exposed. Any highly weathered and fractured zones were removed and otherwise the bedrock was cleaned with an excavator and then manually.

\subsection{Inverted filter}

An inverted base filter was included in the design beneath the upstream portion of the Stage 1 dam. It consisted of a fine filter placed on the foundation till material followed by coarse filter, followed by the rockfill. The purpose of the inverted filter is to reduce the potential for piping of the foundation soils into the rockfill shell of the dam.

For Saddle Dam 1, the inverted filter was constructed beneath the upstream portion of the Stage 1 portion of the dam, and consisted of a $0.5 \mathrm{~m}$ thick layer of fine filter $(20 \mathrm{~mm}$ minus) crushed rock, followed by a $0.5 \mathrm{~m}$ thick layer of coarse filter (200 mm minus) crushed rock. All filter material used in construction, consisted of non-potentially acid generating (NPAG) rock obtained from pit development that had been crushed and transported to the dam site. 
Filter material was hauled and dumped using $100 \mathrm{t}$ mine haul trucks and then placed using an excavator and/or dozer in a single lift. Compaction was performed using a $10 \mathrm{t}$ vibratory smooth drum roller. No water was added during the compaction process due to the cold temperatures.

\subsection{Upstream toe anchor trench}

Initially the design required the liner to be installed and tied into the base of the excavation, and a till plug placed above it. However, as the remaining portion of the dam was not yet constructed, and due to the time of year and climatic conditions during which Saddle Dam 1 was being constructed, concern for the ability to place and adequately compact the layer of till at a later date, led to a decision to raise the liner tie-in, by first placing the till and thereby raising the location of the liner tie-in. This also enabled the liner installation to be done in continuous panels, from the crest of the Stage 1 dam to the toe.

Along the upstream toe of the dam a 4 to $5 \mathrm{~m}$ wide compacted layer of low hydraulic conductivity till material was placed in successive lifts of about $0.5 \mathrm{~m}$ in thickness. The width of the till plug progressively increased. In the toe area, the till was placed up to an elevation about $1 \mathrm{~m}$ below the initial ground surface. On the abutments where bedrock surfaces were exposed, and cleaned, approximately a $0.5 \mathrm{~m}$ thick layer of till was placed and compacted, to provide a smooth surface for geomembrane liner installation.

Till was placed by a dozer, track compacted and then roller compacted with a $10 \mathrm{t}$ vibratory smooth drum roller. The surface of each lift was tracked with the dozer, prior to placement of subsequent lifts to improve the bond between successive lifts.

Good quality, thawed till, with water content near optimum, was located in portions of the dewatered footprint of Second Portage Lake. Locating this source of material was an important factor in being able to complete the construction of the dam, in accordance with the design. Although in the general mine area, a layer of till varying in thickness exists over much of the terrain, this till is either typically frozen, or if not frozen is in the active layer (upper portion of the soil layer) and has a very high water content and not suitable for construction. No moisture conditioning was possible at the time of construction, due to the freezing conditions, which further increased the importance of locating suitable burrow source material that did not require moisture conditioning.

In order to prevent the till from freezing prior to placement, the till needed to be excavated, hauled (about $2 \mathrm{~km}$ ), placed and compacted immediately. Till placement was done as continuously as possible, to reduce the formation of frozen layers within the till plug which could lead to the risk of developing preferential horizontal flow paths. As the till placement extended up the abutments, any till that became frozen near the edges was removed prior to placement of the subsequent lift.

\subsection{Rockfill}

Rockfill formed the structural component of the dam. NPAG rockfill material generated as part of the pit development was hauled to the dam by $100 \mathrm{t}$ mine trucks and placed in successive $2 \mathrm{~m}$ lifts by a dozer. The rockfill was track compacted by the D8 and/or D9 dozer and by routing of the haul trucks over the placed rockfill. Due to the freezing temperatures, no water was added during the construction process. The rockfill shell was raised in steps, of about $2 \mathrm{~m}$ with the filters to reduce the potential for segregation of rockfill along the upstream side of the filters.

\subsection{Upstream filters}

The purpose of the upstream filters is twofold, firstly to reduce the potential for migration of tailings through the rockfill structure and secondly to act as a bedding layer for the geomembrane liner installation.

Upstream filters consisted of a $1 \mathrm{~m}$ thick layer, measured perpendicular to the slope, of coarse filter material and fine filter material. Each lift was about $0.5 \mathrm{~m}$ thick. A lift of coarse filter was placed followed by fine filter. Filter material was hauled and dumped by the $100 \mathrm{t}$ mine trucks and spread primarily by an excavator, although dozers were periodically used for placement. The $10 \mathrm{t}$ smooth drum vibratory roller was used for compaction. Haul trucks were not permitted to travel on the fine filter. Due to the freezing temperatures, no water was added during the construction process. 
The filters were over built and then trimmed back by an excavator to the $3 \mathrm{H}: 1 \mathrm{~V}$. The smooth drum roller was then passed over the trimmed slope in preparation for liner installation.

\subsection{Geomembrane liner}

The low hydraulic conductivity liner system selected for Saddle Dam 1, consisted of a $1.5 \mathrm{~mm}$ thick, textured, linear low density polyethylene (LLDPE) geomembrane liner with an upper and lower $500 \mathrm{~g} / \mathrm{m}^{2}$ non-woven geotextile for protection. A textured liner was selected to improve safety during installation. LLDPE was selected due to its resistance to stress cracking, its multi-axial deformation and tolerance to strains, in recognition of the potential for differential settlement to occur in the foundation soils, by comparison with high density polyethylene (HDPE).

A $500 \mathrm{~g} / \mathrm{m}^{2}$ non-woven geotextile was deployed from the crest of the slope down to the toe and extended out about 1 to $2 \mathrm{~m}$ onto the till surface. Adjacent geotextile panels were overlapped and sandbags were used to temporarily anchor the geotextile, prior to geomembrane liner deployment.

At the toe of the dike the compacted till surface became frozen and was rough and irregular, therefore, on top of the compacted till a thin layer of bentonite powder was spread by hand, to fill in the irregular surface and to improve the contact interface between the liner and the till.

A rub sheet was used beneath each geomembrane panel to provide a smooth surface during geomembrane deployment and to help maintain a clean seam area.

Weather permitting, the geomembrane liner was deployed and welded daily using a thermal fusion (double track hot-wedge) welder. Before welding, trial welds were performed and tested. Non-destructive, air pressure testing of all double track fusion welded seams was performed. Patching was done, as necessary using extrusion welds, and tested using a vacuum box. Although temperatures ranged from approximately -15 to $-25^{\circ} \mathrm{C}$ with wind chill making the temperatures feel even colder, liner deployment, seaming, testing, and repair work was all conducted in the ambient environment, without the use of a heated shelter or other protection. The Geosynthetic Research Institute (GRI) Test Method GM9 deals with cold weather seaming of geomembranes, and generally recommends that seaming of geomembranes not be conducted at temperatures below $-15^{\circ} \mathrm{C}$. Due to the time of year Saddle Dam 1 was being constructed and the mine schedule for tailings deposition, more suitable, warmer weather, would not occur for eight months (May 2010). A decision was taken to proceed with the installation, providing seam test results met specification. Additional destructive samples were collected and tested to confirm welds were meeting the specification. As recommended in GRI Test Method GM9, the field tensiometer was also used to determine the strength of the unseamed geomembrane sheet and these results were compared with seam strength results.

Destructive testing of seams was conducted on selected samples for peel and shear. Portions of samples were retained by the Engineer and sent to an offsite laboratory for verification testing. Once all testing and repairs were made, and approval provided, the upper protective geotextile panels were then deployed.

Challenges during liner installation were caused by strong winds, snow and blowing snow, cold temperatures, and short working days (low levels of light). Delays resulted and slowed production progress for the liner installation. However, the liner was successively installed.

The contractor employed a single tensiometer on site for performing the quality control tests on the trial welds and field seams. Rapid approval of seams was required such that the geotextile layer and protective ballasting weight could be added. Therefore the contractor desired to perform the destructive testing in ambient field temperatures $\left(-15\right.$ to $\left.-25^{\circ} \mathrm{C}\right)$ and at a rate of $50 \mathrm{~mm} /$ minute. The specifications however, referenced ASTM D6392 for peel and shear testing, which recommends testing be done at ambient temperatures (about $20^{\circ} \mathrm{C}$ ) and a rate of $500 \mathrm{~mm} /$ minute for LLDPE geomembrane liners. The standard does note that testing of LLDPE has routinely been performed at rates of 50 and $500 \mathrm{~mm} /$ minute and that the manufacturers recommended procedures be followed.

Therefore, a series of trials were conducted to determine if a correlation could be developed to relate destructive seam peel and shear test results performed under various test conditions. 


\subsubsection{Comparison of destructive test results}

It is well understood that as temperatures increase the tensile strength of geomembranes decrease and tensile elongation increases. Furthermore, the relationship has previously been shown to be linear at least throughout normal conditions of exposure $\left(-25\right.$ and $\left.70^{\circ} \mathrm{C}\right)$ (Giroud et al., 1993; Richards et al., 1985). Tensile property variation as a function of temperature has been previously reported including by Mills and Stang (1997) where correlations between temperature and tensile strength were developed for various geomembranes. However, correlations for LLDPE geomembranes were not reported.

To develop a relationship between results obtained from field tests in a cold environment and tests conducted in the lab at warmer temperature, welded samples were collected and tested under various conditions using the same tensiometer:

- in the field under cold temperatures $\left(-15\right.$ to $\left.-25^{\circ} \mathrm{C}\right)$ at a rate of $50 \mathrm{~mm} /$ minute

- in the lab (approximately $20^{\circ} \mathrm{C}$ ) at a rate of $50 \mathrm{~mm} / \mathrm{minute}$

- in the lab at a rate of $500 \mathrm{~mm} /$ minute.

All test results exceeded the specified values of $328 \mathrm{~N} / 25 \mathrm{~mm}$ for peel and $394 \mathrm{~N} / 25 \mathrm{~mm}$ for shear testing. Not surprisingly, results showed that for both peel and shear testing, values obtained from testing at a slow rate $(50 \mathrm{~mm} / \mathrm{minute})$ in the field, at cold temperatures, were higher than those tested inside, either at a fast or slow rate.

Comparison plots are shown in Figure 4 and Figure 5. Based on the test results, a reduction factor of 35\% and $40 \%$ was established, for shear and peel tests, respectively. The reduction factors were then applied to test results obtained in the field and compared with the values in the specification.

As part of the quality assurance work, selected samples were also shipped to an offsite independent laboratory for testing. This testing was done in accordance with the ASTM D6392, at room temperature and at a rate of $500 \mathrm{~mm} / \mathrm{minute}$. All results met the specification. Similar to the comparison done on site, values of peel and shear obtained by the independent laboratory were lower than those obtained in the field (at cold temperatures) and at a slow rate. Results obtained from testing done on site at room temperature and at a fast rate were similar to those obtained from the independent laboratory. Figures 4 and 5 also show the results of obtained from the independent laboratory, in comparison with those obtained in the field.

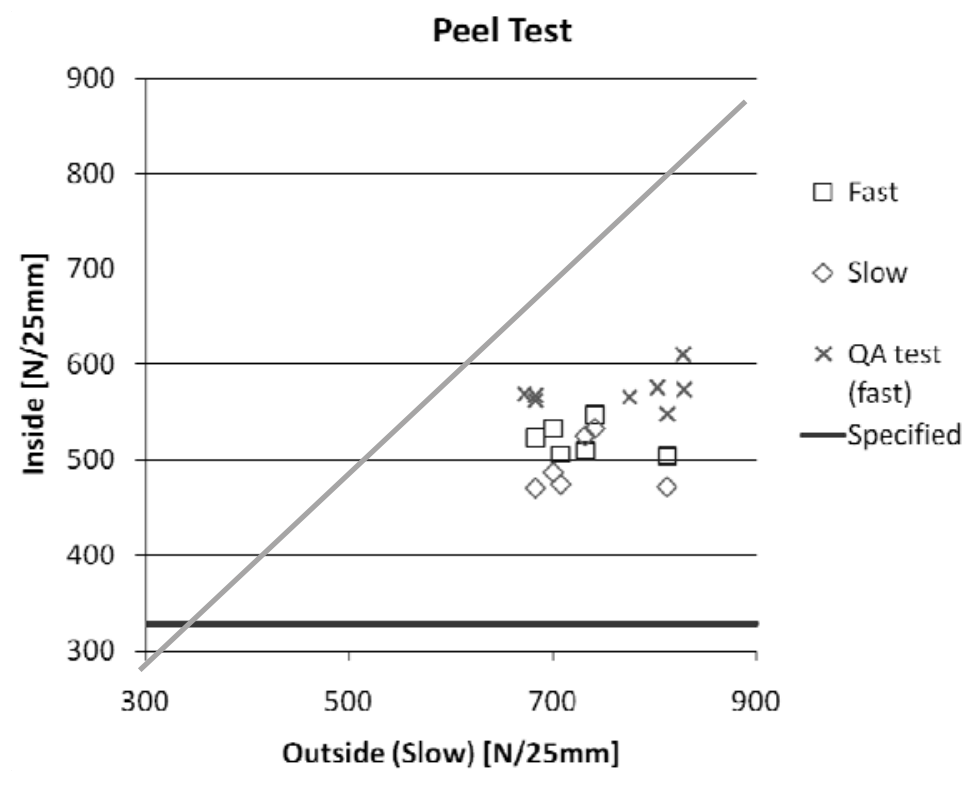

Figure 4 Comparison of peel test results 


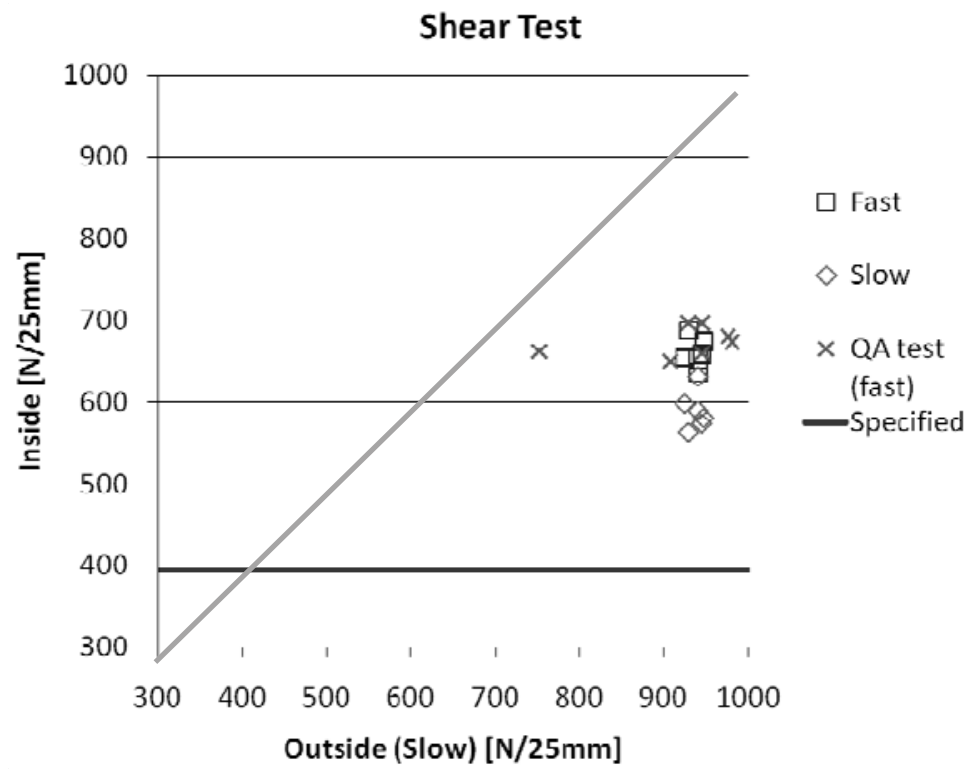

\section{Figure 5 Comparison of shear test results}

\subsection{Protective layer}

At the toe of the dam, above the geomembrane liner, a minimum of $1 \mathrm{~m}$ of fine filter material, mixed with $8 \%$ dry bentonite was placed, followed by another $1 \mathrm{~m}$ of rockfill to provide an access road at the toe of the dam. Samples of the fine filter mixed with bentonite were collected, compacted to $95 \%$ of Standard Proctor maximum dry density, hydrated and tested for hydraulic conductivity. The hydraulic conductivity results were $8 \times 10^{-6} \mathrm{~m} / \mathrm{s}$. An additional layer of rockfill was then placed to provide some confinement and protection for the layer when the bentonite would be exposed to water and cause swelling.

On the upstream face of the dam, above the upper geotextile a $0.3 \mathrm{~m}$ thick (minimum) layer of fine filter was placed to reduce the potential for damage to the LLDPE geomembrane liner by caribou, carnivores, ice, and wind uplift.

In spring/early summer 2010 it is planned to remove the rockfill cover above the fine filter/bentonite mixture and then add an additional till blanket to increase the seepage path near the liner toe.

\subsection{Instrumentation}

One thermistor string has been installed, beneath the liner near the centre of the dam. Two additional thermistor strings have subsequently been installed, one at the upstream toe and one through the crest of the Stage $1 \mathrm{dam}$. All thermistor strings have been installed to monitor the thermal condition and variation over time.

A downstream seepage collection system will also be installed following completion of the Stage 2 raise.

\subsection{Survey}

Due to the relatively quick pace of construction and multiple construction steps occurring simultaneously, having a dedicated surveyor to accurately and frequently obtain as-built information was important for the construction and quality control/quality assurance work.

\section{Saddle Dam 1 - operation}

Production at the Meadowbank Mine commenced during the first quarter of 2010. Tailings are currently being deposited into the north tailings basin of the tailings storage facility. At present, tailings and tailings pond water are not in contact with Saddle Dam 1; maintaining the tailings pond away from the containment structures through the development of long tailings beaches is a key requirement of the deposition plan and facility management activities for both seepage control and thermal protection of the foundation soils. Based 
on the current deposition plan, tailings will begin being deposited, by spigots from Saddle Dam 1 during the fourth quarter of 2010. The operational intent will be to develop a beach in front of perimeter dams, including Saddle Dam 1, and to maintain the supernatant pond within the middle of the facility.

Stage 2 construction of Saddle Dam 1 is planned for 2010, which will see the dam raised to a height of $20 \mathrm{~m}$ and the length of the structure increased to about $400 \mathrm{~m}$.

During spring freshet and through the summer, inspection of Saddle Dam 1 will occur with particular attention paid to any evidence of seepage. A seepage collection system will be constructed downstream of the dam, following completion of the Stage 2 construction. A tailings operational manual, including an operation, maintenance and surveillance (OMS) plan for the Saddle Dam 1 is being implemented by mine personnel.

\section{Lessons learned}

Although dam construction and, in particular, installation of a geomembrane liner in freezing conditions at temperatures below $-15^{\circ} \mathrm{C}$ is challenging, it is possible providing adequate care is taken. For further construction in similar conditions the following recommendations are provided:

- The use of air rotary drilling to assess soil thickness and to collect samples for excess ice content determination (based on excessive water content) is considered an effective tool.

- The removal of ice-rich soil beneath the geomembrane liner is required to reduce settlement and creep over the long term.

- Due to variations in temperature and wind chill, a suitable number of samples of the seams should be collected for testing in the ambient (cold) environment to give the first indication of their quality and then additional testing in a warmer area (i.e. each evening) to confirm results.

- As spigoting of tailings from the dam is not possible until the fourth quarter of 2010, mechanically place tailings, as soon as practical in the spring or early summer, at the toe of the structure to minimise thawing.

- Monitor tailings pond elevations and take measures to ensure the toe of the dam does not become submerged.

- Consider the installation of passive thermosiphons to re-establish the thermal regime following the initial deposition of tailings.

\section{Summary}

Construction of Saddle Dam 1 occurred between August and November 2009, under challenging conditions. At this site, there are particular challenges as a result of the harsh climate, cold temperatures, snow, blowing snow, high winds, frozen ground, including ice-rich soils, and shortened hours of daylight. Additional challenges result from its isolated location, material availability, schedule constraints, and cost constraints. Long term uncertainty as to the thermal conditions is also a concern.

The design and construction of Saddle Dam 1 had to account for these conditions and limitations. The structure was successfully completed, and procedures for managing the tailings facility, monitoring the structure and implementing contingency measures have been developed and will be employed as appropriate.

Saddle Dam 1 is the first in a series of perimeter containment structures of the tailings storage facility at the site. The experience gained during its construction will be used in the design and construction of the future structures.

\section{References}

ASTM D 6392-08 (2008) Standard Test Method for Determining the Integrity of Non-reinforced Geomembrane Seams Produced Using Thermo-Fusion Methods, ASTM International (American Society for Testing and Materials).

Canadian Dam Association (CDA) (2007) Dam Safety Guidelines, Canadian Dam Association. 
Giroud, J.P., Soderman, K.L. and Monroe, M. (1993) Mechanical Design of Geomembrane Applications, in Proceedings Geosynthetics '93 Conference, Vol. 3, Vancouver, Canada, March-April 1993, pp. 1455-1468.

Mills, J.A. and Stang, J.R. (1997) Temperature Corrected Tensile Strengths for Geomembrane Filed Seams, in Geosynthetics 1997, pp. 439-452.

Richards, E.A., Scott, J.D. and Chalaturnyk, R.J. (1985) Cold Temperature Properties of Geomembranes, in Proceedings, Second Canadian Symposium on Geotextiles and Geomembranes, Edmonton, Alberta. 
